\title{
Failed promises - performance measurement ambiguities in hybrid universities
}

\section{Introduction and research setting}

Performance measurement has important and justifiable purposes of transparency, accountability and trust (Lapsley 1988; Mayston, 1993; Porter, 2008; Arnaboldi et al., 2015). Prior research has comprehensively discussed the ambiguities (March, 1987; Espeland and Sauder, 2007), dysfunctions (Smith, 1995), perversions (de Bruijn, 2002) and distortions (Birnberg et al., 1983) as well as paradoxes (Meyer, 2002), of performance measurement. Accounting research has demonstrated ambiguities with respect to what performance measurement actually is (Modell, 2003; 2005; Parker, 2011), what type of knowledge it produces (Johanson et al., 2006; Catasús et al., 2007), how the results of performance measurements are utilized (ter Bogt, 2003; Speklé and Verbeeten, 2014; Kallio et al., 2017) and what kind of impacts it has on institutional performances (Vakkuri and Meklin, 2006; Verbeeten, 2008).

Furthermore, accounting research has succinctly argued that performance measurement is far from a neutral technical artefact to be used to sustain rational order for given a priori purposes. Rather, it is an instrument "in action" the use of which provides and (re)shapes the conditions for organizational action and gives room for enabling, resisting, circumventing and politicking with different institutional orders (Hopwood, 1987). Uses of accounting and performance measurement will continue to create instances for possible potential rationalities, but more importantly, for further forms of ambiguities, disappointments and problems as well (Power, 2015).

In accounting research, performance measurement of universities has been discussed in several papers (Ahrens and Kalifa, 2015; Kallio et al., 2017; Conrath-Hargreaves and Wüstemann, 2019; Dobija et al., 2019). In their qualitative literature review Grossi et al. (2019) classify this tradition into three research streams. First, there is discussion on the dual characteristics and pressures of universities, for instance interplay between global and local steering of universities, corporate and collegial university cultures and "old" and "new" cultures of university organizations. These topics are highly inter-disciplinary addressing and to some extent questioning the trends of university corporatization (Parker, 2011), marketization (Czarniawska and Genell, 2002) and managerialization (Roberts, 2004). In this paper, we intend to provide a more comprehensive understanding of these processes through the lenses of hybridity of universities. Second, accounting research has addressed performance measurement and management systems of universities. This discussion includes for 
instance uses, misuses, and dysfunctional uses of performance measurements at universities (Modell, 2003; 2005; Vakkuri and Meklin, 2006). Our paper provides an important contribution to that discussion by exploring the impacts of hybridity characteristics of universities on the design, uses and misuses of performance measurement systems. Finally, accounting research has quite obviously discussed the introduction of modern financial management systems, including budgeting reforms and cost-accounting models (Edwards et al., 1999).

Furthermore, we can observe that there is some general accounting research regarding impacts of hybridity in institutional systems (Modell, 2005; Parker, 2011; Grossi et al., 2017). This research is mostly related to hybridity aspects of accounting and other related professions (Kurunmäki and Miller 2006), and to the explorative analysis of linking emerging hybrid organizational forms with processes, practices and expertises (Miller et al., 2008). It should be noted that by far this discussion has not been extensively related to hybrid universities. Therefore, we fully agree with Grossi et al. (2019) that there is a particular need in accounting research for more sophisticated theorizations of the ambiguities associated with measuring and reporting performance in hybrid organizations. However, it is even more important to realize that there is a dearth of accounting-related interdisciplinary studies conceptualizing the hybridity of universities with important implications for measuring and reporting performance (Berry 2009). Accordingly, this paper provides more elaborate basis for understanding hybridity of universities, not only through reforms for combining business, government and collegial professional logics (e.g. corporatization, marketization, see later) or through new hybrid mixes of professions, but as a more comprehensive, inter-disciplinary understanding of institutional structures, logics and practices at modern universities. This paper argues that ambiguities of performance measurement at universities could be better understood using the lenses of hybridity.

Our paper contributes to filling this research gap by providing an interdisciplinary theoretical account to performance measurement ambiguities influenced by hybridity and hybrid characteristics of universities (Grossi et al. 2017; Stark, 2009; Skelcher and Smith, 2015). We argue that many limitations of performance measurement research of universities reflect our limited comprehension of the linkages between public and private forms of university activities, as well as distinct forms of value creation that take place outside or beyond organizational boundaries, and connect universities' performance with broader policy goals and agendas (Parker 2011; Miller et al., 2008; van Helden et al., 2008). We ask: how can we understand better those institutional mechanisms through which performance measurement may ultimately result in new forms of ambiguities and unexpected outcomes (Power, 2015; Mouritsen and Kreiner, 2016), and what are the specific characteristics of hybridity that make those possible in universities (Smith and Lewis, 2011; Battilana and Lee, 2014)? 
Performance measurement harbours a promise for a more governable and controllable future (March, 1987; Mouritsen and Kreiner, 2016). While such a promise may help justify the adoption of certain management practices, fulfilling such a promise is a distinct process of interpretation and enactment through which measurers, measurees and measurement audiences invent solutions to application problems in their local settings. Those decisions "set processes in motion that will lead to intended, unintended and surprising effects in the future" (Mouritsen and Kreiner, 2016: 22). The modern hybrid university is a good example where performance measurement involves significant potential rationalities by reducing goal ambiguity, enhancing accountability, increasing legitimacy and transparency and making sense of complicated environments. However, for several reasons we theorize in detail, the outcome of performance measurements may be something different, sometimes even the opposite. Our paper explains why and to what extent these unintended effects of performance measurements are influenced by hybrid characteristics of universities. We also demonstrate situations where measurements incentivize hybrid universities to benefit from ambiguities.

The argumentation of our paper is explorative, conceptual and inter-disciplinary. With an interdisciplinary approach we aim to avoid the potential shortcoming of accounting research on hybrids recognized by Miller et al. (2008: 961): “....and as topics of research [hybrids], they also fall between the conventional academic disciplines of accounting, economics, law, organisation theory and the sociology of the professions, which may in part explain their neglect by researchers". Our argumentation draws upon interdisciplinary insights from accounting, public administration and management, higher education policy and management as well as economic sociology (Parker and Guthrie, 2014). With that perspective, we analyse theoretico-conceptual links between the promise and the potential rationalities of performance measurement, performance measurement principles "in action" in hybrid universities, and the decision-making ambiguities resulting from performance measurement dynamics. Instead of aiming at empirical argumentations that could be relevant for understanding particular types and contexts of university systems, we seek a more general conceptual contribution to exploring performance measurement ambiguities in hybrid universities.

This article proceeds as follows. In the next section, we discuss the main characteristics of hybrid forms of governance in society and hybridity in universities. The third section connects promises of performance measurement with the hybridity characteristics of universities, applies these to the measurement design of universities and discusses the further forms of ambiguities in universities. The fourth section provides a synthesis of the forms of ambiguities in hybrid universities as a single conceptual model. The final section examines the implications of our analysis of hybridity for 
performance measurement research in general and for understanding university performance in particular.

\section{Performance and hybridity in universities}

\subsection{Why hybridity and hybrid governance?}

Hybridity refers to the combination of two or more pure species that integrate species in a novel fashion. In this way, hybridity may be seen as a form of impurity combining aspects of their original inheritance. Biological analogies lack a clear reference point in institutional life, as organizations do not have DNA to enable breeding or a definite period of existence. In institutional settings, hybridity may refer to several enmeshed aspects, such as politics and administration (Aberbach et al., 1981), markets and hierarchies (Powell, 1990; Williamson, 1999) or a multiplicity of professional expertise (Noordegraaf, 2007). Indeed, contemporary institutional systems combine features of both private and public management and governance in several ways. Consider the following forms:

a) Mixed ownership between public and private actors (e.g. state-owned enterprises [SOEs] pursuing politically driven goals, while exploiting business logics and operating in global financial markets (Thynne, 2011).

b) Goal incongruence and competing institutional logics between the logic of profit-seeking, vis-àvis the logic of effectiveness, with social impacts on society and citizens (e.g. healthcare firms using business logics supplementing or replacing the public provision of healthcare or social enterprises attempting to "do well by doing good" (Reay and Hinings, 2009; Kreps and Monin, 2011; Pache and Santos, 2013; Conrath-Hargreaves and Wüstemann, 2019).

c) Multiplicity of funding arrangements between public and private actors, including investors and financiers (e.g. several types of public-private partnership arrangements in financing public service delivery [Hodge and Greve, 2007]).

d) Public and private forms of financial and social control, including regulatory control of the markets, professional self-control and customer-driven market control within a single system of service delivery (e.g. multi-faceted control and audit systems of organizations operating based on professional clan control and customer-driven satisfaction logics [Power, 2000]).

Some of these features have increased due to market-based reforms driven by the quest for modernity and legitimacy. Some involve the timeless questions of organizing and service delivery explained by the inherent complexities of goal setting, resource allocation and measurement (Skelcher and Smith, 2015). It is difficult to see hybrids and hybridity merely as inventions of the New Public Management (let alone New Public Governance) epoch. As Badian (1983) concisely argued, even the ancient Romans had hybrid forms of governance. However, the impurity of hybrid governance has raised concerns regarding how to tame the monstrous characteristics of hybridity. One conspicuous argument is that offered by Jacobs (1992), who suggested that even though governments and markets 
each have deficiencies, both are needed by society. The real threat comes with the introduction of monstrous hybrids combining hierarchical government with fluid business practices, which both corrupts government activity and distorts healthy profit-seeking.

Performance measurement practices have been gradually integrated into the classic principles of political decision-making and budgeting, where efficiency has always been an issue of concern, not in terms of profit-seeking, but through seeking procedural parsimony. Another aspect of such reforms has been the outsourcing and privatization of portions of the public sector. The illusion of such developments is that the privatization of activity results in pure market activity. The comparative evidence illustrates that government regulations have increased in tandem with the adoption of market-based reforms (Jordana and Levi-Faur, 2004). It is quite plausible that governments aim to secure political influence in those areas involving the public interest or the strategic assets of the government. In a discussion of "publicness", this development refers to the simultaneous increase in both private and public authority (cf. Bozeman, 1987): public in terms of the increased regulation and private in terms of the introduction of profit motives. Such a constellation more closely signifies the practice of regulations in guiding natural monopolies, rather than the hierarchies or hybrid contracting approaches of competitive markets (Williamson, 1999).

\subsection{Universities as hybrid assemblages}

Universities offer a particular framework for hybrid arrangements. It is not at all easy to characterize universities as purely public or private (cf. Marginson, 2007). In fact, universities can be considered hybrids according to all four characteristics defining hybrid activities. The problem of ownership has raised questions concerning "who actually owns universities" (Farrington, 2000; Shore and Taitz, 2012). Furthermore, the incongruence of universities' different goals and institutional logics impacts discussions of whether the goods of scientific knowledge production should be defined as public or private (Marginson, 2007; Parker, 2011). The multiplicity of funding sources from public and private pockets is, according to some scholars, transforming universities into "entrepreneurial" institutions (Etzkowitz et al., 1998; Modell 2003). Finally, as always in history, societies are eager to control universities and their activities through various public and private means (Clark, 1983).

Universities' main activities are research, teaching, and the third mission. These activities are hybrid by nature, and societies find legitimate arguments to justify the production of these activities, known as "goods", in the marketplace. Examples include commissioned research projects, higher education degrees funded through student tuition fees and university-related consultancies intended to support 
local business clusters. However, the same activities involve significant externalities and spillover effects, which constitute an important basis for long-term economic growth and development and are, accordingly, lucrative targets of public and private control (Marginson, 2007). It is no wonder that universities have become elementary components of triple helix and even quadruple helix constellations, in which mixed ownership and different parallel institutional logics work in unison with complicated mechanisms and systems of funding, as well as institutional control practices (cf. Colapinto and Porlezza, 2012). As hybrid assemblages, universities cannot be reduced to hybrid "organizations". Rather, they belong to meso-level systems of hybrid activities (or fields) or even macro-level systems of research, development and innovation (Johanson and Vakkuri, 2017).

A distinctive feature of universities that sets the scene for performance measurement problems is known as the academic oligarchy (Clark, 1983). Clark's notion of the coordination triangle entails the control of the state, markets and the self-control by the academic profession. These forces may be treated as mutually exclusive, meaning that a decrease in state control leads to more control by the markets or the academic oligarchy. This may involve a higher resource dependency on the markets (e.g. external sources of funding) and/or more locally determined forms of coordination and control. This may be a constraining assumption, as many university systems are de facto influenced by simultaneous changes in policy control. However, it gives us an important theoretical viewpoint for understanding the characteristics of hybridity in university systems.

\section{Performance measurement in action - promises, measurement principles and ambiguities in hybrid universities}

Performance measurement is a form of constructed certainty. The ways in which certainties are constructed, mobilized and enacted are another facet of performance measurement in action (Johanson et al., 2006; Catasús et al., 2007). We theorize the dynamic nature of performance measurement by connecting three elements: 1) promises and potential rationalities of performance measurement in hybrid universities, 2) performance measurement in action as introducing the institutional mechanisms through which performance measurements of universities are influenced by hybridity characteristics, and 3) ambiguities that are of specific importance to universities as characteristics of their hybridity are systematically analysed.

Our way of integrating performance measurement principles into the discussion stems from the characteristics of hybridity and hybrid activities (Grossi et al., 2017). It is important to understand the 
roles and interests of key actors with respect to ownership, finance or control, or associated with the goals and agendas of measurements, measurers and measurees (cf. ownership, institutional logics, finance and control as criteria of hybridity). Therefore, for understanding the ambiguities of performance measurement of hybrid universities, there are objects of measurement to be identified (hybrid universities as measurees), there are those who measure with distinct interests and agendas (measurers of hybrid universities), measurement interactions are influenced by distinct rule systems (measurement rules) and there are audiences of measurement results (measurement results) (Ijiri, 1975; van Helden et al., 2008; Johanson and Vakkuri, 2017). Through these actor constellations, objects of performance are formed and elaborated, measurement activities are orchestrated and infrastructure for governing measurement systems are initiated and developed (Power, 2015: 43-45).

\subsection{First promise: understanding the mission of universities}

Consider the vast repertoire of significant, yet ambiguously defined activities and societal impacts to which universities are expected to contribute: educational intelligence, intellectual capital, local and regional economies, research and development (R\&D) systems and technological transformation and restructuring, among others. The problem is how to do this and who might be responsible. Given the undefined scope of hierarchical control, it is not always helpful to call a university rector. This also implies a general gap in expectations between perceptions of universities as promoting society's common good and actual opportunities for fulfilling those desires. This gap is not only decision talk (Brunsson, 1989); it also refers to universities' complex work processes (Knorr-Cetina, 1999), ambiguous and ambivalent preferences and identities (Merton, 1976), garbage-can type decisionmaking and loosely coupled organizational structures (Weick, 1976; Meyer, 2007).

\section{Promise 1: Performance metrics enable universities to understand their actual mission.}

\subsubsection{Performance measurement in action - hybrid universities as measurees}

It is common to measure hybrid activities through organizational foci (i.e. as hybrid "organizations"). However, to understand hybrid forms of action, it is crucial to go beyond the organizational emphasis. We may think of hybrid "systems": policy-level networks of institutions and actors pursuing societal macro-level goals, but with different sets of institutional backgrounds and logics. We may also observe hybrid "industries" or "fields", in which clusters of public and private actors converge in pursuing a public goal within a specific forum of action. Performance measurement solutions may 
vary across micro- (organization), meso- (field) and macro- (system) levels of hybrid governance (Grossi et al., 2017). There are different types of hybrids, not only with respect to their level of hybridity but also with respect to the tasks at hand (Kastberg and Lagström 2019). University organizations (as units of higher education) may be shaped and controlled by different sets of boundaries and reputation mechanisms than the intellectual fields that constitute the basis of university activities (Whitley, 2000).

At universities, ambiguities of performance measurement systems stem from (1) hybridity itself and (2) the complexity of valuing performance criteria assigned by institutions of external accountabilities and the academic oligarchy. Assumptions concerning how to understand universities' performance vary across three viewpoints (Clarke, 1983). For market measurers, university performance concerns the interactions between universities and their external partners and constituencies (Modell, 2005). For state measurers, universities are successful to the extent to which they are able to contribute to the objectives of higher education policies. The academic oligarchy tends to emphasise the uniqueness and novelty of scientific research and teaching.

As defined by the matrix of a scientific research system, vis-à-vis a formal educational system, universities can be seen as a collection of invisible colleges in which the boundaries between different activities and institutional structures are decoupled, dispersed and widely distributed (Crane, 1972). Therefore, whose performance should we actually measure: that of the formal bureaucratic "university organization", the research organization transcending the formal boundaries of universities or, for instance, that of the university-industry clusters constituting new types of hybrid governance (Powell and Owen-Smith, 1998)?

Hybridity among universities is not solely organization-based (cf. Luke et al., 2013: 242-243). Universities are understood as parts of national innovation systems (Nelson, 1993). Within industrialized countries, national innovation systems are tools for technological advancement to survive in global competition. By nature, national innovation systems are linked to the idea of a nation-state, but in reality, they consist of several different levels of aggregation. This view of a national innovation system promotes a more encompassing view of innovation as embedded in government policies, university research, industry structures and the environment, and national innovation systems are evident in micro-level interactions. The triple helix concept grew from the government-industry dyad to the government-university-industry triad (Ranga and Etzkowitz, 2013). 


\subsubsection{What is a hybrid university as a measuree? Organizational lock-in problem}

Performance measurement models essentially rely on the primacy of organizational reasoning in which measurees are defined by the assumption that the rationality of a system may be examined by summing "local" rationalities (i.e. those of individual entities and agencies) within a larger whole. This reflects a sequential, linear process of evaluating complicated societal activities (Hopwood, 1996). Performance measurement focuses on the rationality of mechanisms through which "organizational" goods transform into "public" or "common" goods. Such an assumption is inapt for addressing either a plethora of action (and actor) interdependencies or understanding the mechanisms of hybrid universities (Hodges, 2012).

The commitment to organizational reasoning constrains the ways in which performance can be understood in the university context. Due to what we call the organizational lock-in problem, we may be unable to grasp all the important dimensions of university performance. While we should be able to understand performance through the complicated webs of interactions among micro-, meso-, and macro-levels of activities, there may be excessive emphasis on the level of university organizations (Luke et al., 2013). In addition to the level of organizations, we should focus on performance measurement among groups of organizations (organizational fields, or the meso-level) and within organizational populations as a system-level construct. The expectations gap of what universities can achieve reflects an assumption of organizational focus, and it may lead to excessive simplifications of causal inferences regarding what hybrid universities are actually able to contribute.

\subsection{Second promise: making universities more accountable}

Accountability has significant impacts on the ways in which performance measurement systems are designed and utilized, as well as on the kinds of problems universities encounter when confronted with performance measurements (Mulgan, 2000; Schillemans, 2011). The mixing of different missions, interests and institutional logics, as well as public and private forms of finances, within the same administrative structure can limit the applicability of generic accountability principles to a hybrid university. For this purpose, performance measurement may be used as an important solution (Grossi et al., 2017). Accountability problems open possibilities for performance measurement to verify actors' multiple responsibilities, avoid dual commitments to the public and private spheres and assign credit or blame based on hybrid universities' performance (Crofts and Bisman, 2010).

Promise 2: Performance measurement makes universities more accountable. 


\subsubsection{Multiple measurers of hybrid universities}

In the university setting, the system of information exchange between accountors and accountees does not necessarily comply with the vertical accountability mechanisms of hierarchical systems for two reasons (Hodges, 2012). First, in the university context, accountees are not always hierarchically superior to accountors; rather, a system may include several vertical and horizontal accountability relationships, and it is not always clear who is accountable to whom (Ebrahim et al. 2014). Second, the measurement of hybrid universities is particularly characterized by many accountees with distinct performance measurement interests. Therefore, it is not easy to attribute credit and blame or sanctions and rewards. Who should be given the credit for positive outcomes related to "regional economy," “intellectual capital” or "functioning labour markets?" Universities may have a contribution, which is, however, difficult to demonstrate, measure or, let alone, monetarize.

Hybrid universities need to measure performance against several competing yardsticks. Accordingly, there are many measurers, with different measures reflecting different accountability demands and interests related to performance (van Helden and Reichard, 2019. The measurers fall into measurers by the market (notably, students and companies collaborating with universities), state measurers (e.g. ministries and other levels of politico-administrative policy apparatus) and academic oligarchy measurers (e.g. peers, colleagues, and other university institutions). Due to these groups' inherently various measurement interests, it is difficult to provide a coherent, unanimous notion of university performance. What is more, demands for more detailed measurement may well surface controversies that have remain hidden in a more ambiguous measurement regime.

\subsubsection{Problem of multiple accountabilities}

The accountability dilemma in university contexts may facilitate "pathologies" that originate from the combination of multiple measurers and their multiple institutional logics (Conrath-Hargreaves and Wüstemann, 2019; Dobija et al., 2019). Due to their multiple measurers, universities may suffer from an audit explosion: an excessive number of audit and metrics systems based on dissonant control rationalities. However, there may also be absolute caveats in terms of controllability and appropriate audit trails. Universities may not be subject to public accountability, or they may even fall outside any form of accountability through creative forms of compliances (Power, 2000: 115). Moreover, the relative importance of public and private goals may collide, such that a hybrid university may have to compromise public goals and the role of government as an impartial regulatory actor. 
Performance measurements are assumed to contribute to a single, coherent notion of core accountability in hybrid contexts in which hybrid organizations must account to an external authority (cf. Mulgan, 2000; Ebrahim et al., 2014). Instead, different measurers' different interests and emphases on their own distinct responsibility ideals lead to something Koppell (2005) has labelled "multiple accountabilities disorder". This takes two forms. First, a hybrid university may attempt to be accountable, but in the wrong sense of the word. A university may be held accountable in areas outside its control. From this perspective, adding new layers of accountability may cause audit explosion or control over things that are not relevant or do not contribute to performance improvement. Second, the accountability dilemma may motivate hybrid universities to be accountable in every possible sense (Power, 2000). They end up pleasing no one while trying to please everyone.

\subsection{Third promise: simplifying goal ambiguity in universities}

Goal ambiguity is well known in the university context, and it is an important priority for university managers (March, 1987; Modell, 2003; Parker, 2011). To address the problem, managers use measurements to create calculative orders, to make sense of organizational missions and to enhance the transparency of university activities. Thus, performance measurement may help cope with goal ambiguity (i.e. survival in situations involving no unified interpretation of a university's goals). Performance metrics may provide a form of calculative order for universities by creating an illusion of control, clarity and minimal ambiguity. This may be fabricated through notions of how to understand university performance, how to provide information and knowledge on university performance and how to facilitate uses of performance metric systems (Vakkuri and Meklin, 2006).

Promise 3: Performance metrics render ambiguous goals of universities comprehensible and transparent.

\subsubsection{Rules of performance measurement in hybrid universities}

Hybridity logics impose particular problems on the design of performance measurement rules. If the measuree is (or becomes) hybrid, the system of quantification should be able to trace that hybridity (Kastberg and Lagström 2019). However, contemporary theoretical thinking lacks important theoretical flexibility (Miller et al., 2008; Grossi et al., 2017). Traditional measurement rules are at their best with stable measurees and institutional environments (divided into "public" and "private"), as well as easily verifiable processes, outputs and outcomes. As difficult-to-measure environments, 
universities must balance conflicting expectations and measurement practices. Consider the three performance measurement perspectives regarding market measurers, state measurers, and academic oligarchy measurers in the university context. If universities are expected to positively impact society through science or higher education policies, for instance, measures of effectiveness usually refer to the attainment of policy goals. On the other hand, if the effectiveness of universities should be defined and evaluated by users, customers or students, the set of measurements must be different (Modell, 2005).

In general, there are two important ways of solving the problem of measurement rules in universities. Firstly, one may assume that universities can be measured using the characteristics of pure types of public and private forms of institutional action, facilitating mechanisms of rule diffusion between public and private. In this approach, universities may be measured through the types of financial accounting statements used in private firms, as well as through government budgetary accounting methods. Here, we face the problem of transposition (Padgett and Powell, 2012). Performance measurement rules are not simply transferred from one area of activity to another; instead, they are given new meanings and interpretations to fit into the new context of measurement. Measurement rules reshape the ways in which performance is assessed in different contexts.

Secondly, an important rule for measuring university performance is to treat universities as "organizations". Performance measurement follows an entity-based notion of the organizational system (Hopwood, 1996), which is aligned with traditional systems theory and its clear-cut boundaries between measuree and environment. According to the rule system, to measure the performance of a university, one must distinguish its activities from its "environment": in other words, one must differentiate controllable and uncontrollable factors (Allen, 2012). Moreover, measurement rules are designed to distinguish the performance of university $\mathrm{X}$ from the performance of university Z. It is easier to demonstrate vertical rather than horizontal accountabilities, for which the budgeting of government resources is assumed to follow the boundaries of distinguishable accounting entities (Hodges, 2012).

\subsubsection{Ambiguity of simplification in hybrid universities}

The objective of replacing the institutional impurity of hybrids with perceived calculative orders, or decision-making ambiguity with clarity, is a sensible promise for performance measurement. However, due to the limitations of the rule systems of performance measurement, particularly the 
emphasis on accounting entity-driven measurement design, we are not able to fully understand the performance measurement of hybrid universities. On the contrary, in many cases, existing measurement rules and statistical classifications not only make hybrid arrangements invisible, but also distort the performance assessment of both public and private activities (Nicholls, 2009; Vries and Yehoue, 2013). Consequently, we either give undue credit or assign blame to universities without sufficient causal reasoning. Performance measurement does not always simplify the world of universities as expected; instead, due to hybridity characteristics of universities, performance measurement makes that world even more ambiguous.

\subsection{Fourth promise: making universities more legitimate through performance measurements}

In the institutional world, the more different you are, the more complicated your life may become (DiMaggio and Powell, 1983). In hybrid universities, this observation has important implications. With ambiguous missions, difficult-to-measure outputs and conflicting logics of preferences and choices, points of reference become increasingly important. For legitimacy, universities must be connected to other universities, organizations and actor networks. Measurement is an instrument for such introducing such connectedness and comparability. Hybrid universities can demonstrate their legitimacy if they appear comparable and, respectively, if their performance can be modelled against acknowledged reference points. In some cases, this may transform university behaviour towards the average of university populations, making them not only more average, but also more transparent and comparable (Llewellyn and Northcott, 2005). Performance measurements may contribute to the legitimacy of hybrid universities by increasing connectedness and facilitating mechanisms of emulation.

Promise 4: Performance measurement enhances institutional legitimacy of universities.

\subsubsection{Performance measurements for legitimizing university activities}

Due to its multiple audiences and their distinct interests, the university context integrates three approaches to using measurement results. It is relevant to understand the uses of performance measurement through which institutions legitimize their activities. In addition, in terms of legitimization through performance information, it is important to identify the audiences for the justification of actions (Boltanski and Thévenot, 2006; Luke et al., 2013; van Helden and Reichard, 2019). 
Furthermore, the multiple audiences of legitimization require different legitimization strategies. From the viewpoint of the academic oligarchy, legitimization strategies focus on variation, novelty and uniqueness in knowledge production. To achieve this purpose, performance information is utilized and interpreted to differentiate one university from others based on its ability to produce novel knowledge. In this context, it makes sense for universities to be positive outliers. Quite naturally, legitimization strategies may also produce convergent behaviours among universities, as differentiation is rarely an easy task. In contrast, state control may emphasise conformity and convergence to foster the comparison of universities, research and teaching outcomes across units and institutions. The main emphasis here is on the attainment of wider policy goals. From this perspective, it makes sense to impose comparative assessments. Finally, the market logic incentivizes legitimization strategies through an emphasis on satisfaction, competition and choice. Performance information is used to legitimize university activities through evaluations by industrial partners in collaborative projects, by students (understood as "customers") or by other constituencies with a stake in university activities.

There is a need to balance measurement systems between different audiences of legitimization in universities. This has several implications. Firstly, it is likely that the number of performance indicators tends to increase, as different sets of performance measurements appear legitimate for different audiences. Secondly, different measurements create different types of calculative spaces. Consider arguments in favour of a single bottom line indicator for university performance. Quite often, this bottom line reflects only one limited perspective. Thirdly, universities may use multiple audiences and practice gaming behaviours by focusing on those audiences (and measurements) that are most favourable to them, omitting poor measurements with the justification of "comprehensive assessments".

\subsubsection{Multiple audiences of hybrid universities - problem of legitimacy bifurcation}

For whom should hybrid universities legitimize their activities? This question raises important concerns, but also presents opportunities. Universities are not required to legitimize their activities for all audiences. Nobody expects them to be loyal to all principles. Instead, some audiences are more flexible regarding the ambiguity of accountabilities, which provides leeway for universities to select those audiences by whom they wish to be evaluated. In the same vein, stakeholders recognize the ambiguity of value creation (Nicholls, 2009). Thus, it may be easier for universities to choose the modes of value they wish to demonstrate and to not disclose those forms of value they wish to hide. 
This may permit universities to legitimize their performance by selecting the audiences to which they wish to be visible and transparent. Due to legitimacy bifurcation, instead of contributing to legitimacy, performance measurements can incentivize universities to offer false promises, opportunistic behaviour and practice gaming strategies, encouraging them to strengthen their legitimation base by harvesting approval from multiple sources (Bruton et al., 2015).

\section{Combining ambiguity perspectives of performance measurement in hybrid universities}

As performance measurement offers a promise of a more governable, controllable and rational future (Mouritsen and Kreiner, 2016), in hybrid universities, promises of performance measurement are put to the test in a fairly static, organizationally constituted and accounting entity-driven system of performance measurement. Variations of performance measurement ambiguities in hybrid universities are synthesized in Table 1.

*********INSERT TABLE 1 AROUND HERE*************

Table 1 connects the hybridity characteristics of universities with the four measurement principles and provides a conceptually revised notion of performance measurement ambiguities. The ambiguity of performance measurement in hybrid universities originates from rational intentions for using performance measurements to make hybrid universities more comprehensible, accountable and legitimate. However, when measurement principles, which are designed to satisfy their own local rationalities, are connected with hybridity logics of universities, we encounter often unexpected outcomes and new variations of performance measurement ambiguities. Our analysis suggests four such variations and explains what happens with performance measurement "in action".

\section{Conclusions and discussion}

This paper provides an interdisciplinary contribution to the research on performance measurement of hybrid universities. We argue that the hybrid nature of universities evade any single-minded promises backed by accounting and measurement regimes. Universities are rife with nuanced forms of 
hybridity where static, institutionally inflexible measurement rules cannot grasp their diverse ownership and institutional logics as well as diversified funding schemes and control mechanisms. This paper has developed an approach of combining several disciplinary traditions for more elaborate theorizations regarding the impacts of hybridity on performance measurement of universities, and, ultimately, for "recognising the nature of accounting and accountability issues, as well as diagnosing and addressing them" (Parker and Guthrie, 2014: 1221-1222).

Our paper demonstrates the extent to which promises of performance measurements may remain unfulfilled in hybrid universities. We have proposed a conceptual scheme to investigate the impacts of hybridity and hybrid governance on the ways in which performance is reported, enacted and communicated in institutions (Grossi et al., 2019) and on how the context of hybridity may instigate new variations of performance measurement ambiguities, disappointments and problems (Power, 2015). Therefore, understanding ambiguities may teach us important lessons on performance measurement itself (March, 1987; Mouritsen and Kreiner, 2016).

The implications of our article are two-fold. First, in addition to the common understanding that there may be significant problems in transposing measurement ideals from private to public sector activities, it is even more important to understand the parallel interactions of performance measurement principles, actors and ambiguities in institutional contexts where "public" and "private" interact and collaborate, but also compete, collide and conflict. This is an important opportunity for accounting research. Second, studies have to be able to combine the perceived virtues of performance measurement with hybridity characteristics in a particular institutional context. For instance, the role of academic oligarchy makes hybridity of performance unique in the university context by providing complicated interactions between distinct forms of governance, measurements and professional logics (Miller et al., 2008). Accordingly, we observe new promises of performance measurement, but also further forms of ambiguities that are of particular type. This paper demonstrates how ambiguities of performance measurement at universities can be better understood using the lenses of hybridity.

Our conscious choice was to focus on only one illustrative and important institutional context: hybrid universities. It is important to notice that the level, extent and outcomes of hybridity may vary with respect to different university systems, governments and nation-states. There is considerable potential for empirical studies on the hybridity characteristics in different university systems. Moreover, this paper has raised the question to what extent the promises of performance measurement and their respective ambiguities may vary vis-à-vis different environments of hybrid governance in general. It 
would be of value to apply this reasoning to, for example, healthcare, infrastructure, social enterprises or other relevant institutional environments.

\section{References}

Aberbach, J., Putnam R. and B. Rockman (1981), Bureaucrats and Politicians in Western Democracies, Harvard University Press, Cambridge and London.

Ahrens T. and Khalifa R. (2015), The impact of regulation on management control: compliance as a strategic response to institutional logics of university accreditation, Qualitative Research in Accounting \& Management, Vol. 12 No. 2, pp. 106-126.

Allen, D. (2012), The Institutional Revolution: Measurement and the Economic Emergence of the Modern World, University of Chicago Press, Chicago.

Arnaboldi, M., Lapsley I. and Steccolini I. (2015), "Performance management in the public sector: the ultimate challenge", Financial Accountability \& Management, Vol. 31 No. 1, pp. 1-22.

Badian, E. (1983), Publicans and Sinners: Private Enterprise in the service of the Roman Republic, with a Critical Bibliography, Cornell University Press, Ithaca.

Battilana, J. and Lee M. (2014), "Advancing research on hybrid organizing - insights from the study of social enterprises", The Academy of Management Annals, Vol. 8 No. 1, pp. 397-441.

Berry, A.J., Coad, A.F., Harris, E.P., Otley, D.T. and Stringer, C. (2009), "Emerging themes in management control: a review of recent literature", The British Accounting Review, Vol. 41 No. 1, pp. 2-20.

Birnberg, J.G., Turopolec L. and Young S.M. (1983), “The organizational context of accounting”, Accounting, Organizations and Society, Vol. 15 No. 2/3, pp. 111-129.

Boltanski, L. and Thévenot L. (2006), On Justification: Economies of worth, Princeton University Press, Princeton.

Bouckaert, G. and Halligan J. (2008), Managing Performance. International Comparisons, Routledge, London.

Bozeman, B. (1987), All Organizations are Public: Bridging Public and Private Organizational Theories, Jossey-Bass, San Francisco.

Brunsson, N. (1989), The Organization of Hypocrisy: Talk, Decisions and Actions in Organizations, Wiley, New York. 
Bruton, G.D., Peng, M., Ahlstrom, D., Stan, C. and Xu, K. (2015), "State-owned enterprises around the world as hybrid organizations", Academy of Management Perspectives, Vol. 29 No. 1, pp. 92-114.

Catasús B., Ersson S., Gröjer J-E. and Wallentin F. (2007), "What gets measured gets ... on indicating, mobilizing and acting”, Accounting, Auditing \& Accountability Journal, Vol. 20 No. 4, pp. 505-521.

Clark, B. (1983), The Higher Education System: Academic Organization in Cross-National Perspective, University of California Press, Berkeley.

Colapinto, C. and Porlezza, C. (2012), "Innovation in creative industries: from the quadruple helix model to the systems theory", Journal of the Knowledge Economy 3: 343. https://doi.org/10.1007/s13132-011-0051-x.

Conrath-Hargreaves A. and Wüstemann S. (2019), "Multiple institutional logics and their impact on accounting in higher education: the case of a German foundation university", Accounting, Auditing \& Accountability Journal, https://doi.org/10.1108/AAAJ-08-2017-3095.

Crane, Diana (1972), Invisible Colleges: Diffusion of Knowledge in Scientific Communities, University of Chicago Press, Chicago.

Crofts K. and Bisman J. (2010), "Interrogating accountability: an illustration of the use of Leximancer software for qualitative data analysis", Qualitative Research in Accounting \& Management, Vol. 7 No. 2, pp.180-207.

Czarniawska, B. and Genell, K. (2002), "Gone shopping? Universities on their way to the market", Scandinavian Journal of Management, Vol. 18 No. 4, pp. 455-474.

De Bruijn, H. (2002), Managing Performance in the Public Sector, Routledge, London.

DiMaggio, P. and Powell W. (1983), “The iron cage revisited: institutional isomorphism and collective rationality in organizational fields", American Sociological Review, Vol. 48 No. 2, pp. 147-160.

Dobija D., Górska A.M., Grossi G. and Strzelczyk W. (2019), "Rational and symbolic uses of performance measurement: Experiences from Polish universities”, Accounting, Auditing \& Accountability Journal, https://doi.org/10.1108/AAAJ-08-2017-3106.

Ebrahim, A., Battilana J. and Mair J. (2014), "The governance of social enterprises: mission drift and accountability challenges in hybrid organizations", Research in Organizational Behavior, Vol. 34, pp. 81-100.

Edwards, P., Ezzamel, M. and Robson, K. (1999), "Connecting accounting and education in the UK: discourses and rationalities of education reform”, Critical Perspectives on Accounting, Vol. 10 No. 4, pp. 469-500.

Espeland, W. and Sauder, M. (2007), "Rankings and reactivity: how public measures recreate social worlds", American Journal of Sociology, Vol. 113 No. 1, pp. 1-40. 
Etzkowitz, H., Webster, A. and Healey, P. (Eds.) (1998), Capitalizing Knowledge. New Intersections of Industry and Academia, State University of New York Press, Albany.

Farrington, D. (2000), "Who owns universities?", Perspectives: Policy \& Practice in Higher Education, Vol. 4 No. 1, pp. 21-24.

Grossi G., Reichard C., Thomasson A. and Vakkuri J. (2017), Theme: performance measurement of hybrid organizations - emerging issues and future research perspectives, Public Money \& Management, Vol. 37 No. 6, pp. 379-386.

Grossi, G., Kallio, K., Sargiacomo, M. and Skoog, M. (2019), "Accounting, performance management systems and accountability changes in knowledge-intensive public organizations", Accounting, Auditing \& Accountability Journal, https://doi.org/10.1108/AAAJ-02-2019-3869

Hodge, G. and Greve C. (2005), The Challenge of Public Private Partnerships: Learning from International Experience, E. Elgar, Cheltenham.

Hodges, R. (2012), "Joined-up government and the challenges to accounting and accountability researchers", Financial Accountability \& Management, Vol. 28 No. 1, pp. 26-51.

Hopwood, A. (1987), "The Archaeology of Accounting systems", Accounting Organizations and Society, Vol. 12 No. 3, pp. 207-234.

Hopwood, A. (1996), "Looking Across Rather Than Up and Down: On the Need to Explore the Lateral Processing of Information”, Accounting, Organizations and Society, Vol. 21 No. 6, pp. 589-590.

Ijiri, Y. (1975), Theory of Accounting Measurement, American Accounting Association, Sarasota.

Jacobs, J. (1992), Systems of Survival: A Dialogue on the Moral Foundations of Commerce and Politics, Random House, New York.

Johanson U., Skoog M., Backlund A. and Almqvist R. (2006), "Balancing dilemmas of the balanced scorecard", Accounting, Auditing \& Accountability Journal, Vol. 19 No. 6, pp. 842-857.

Johanson, J-E. and Vakkuri, J. (2017), Governing Hybrid Organisations. Exploring Diversity of Institutional Life, Routledge, London/New York.

Jordana, J. and Levi-Faur D. (2004), The Politics of Regulation: Institutions and Regulatory Reforms for the Age of Governance, E. Elgar, Cheltenham.

Kallio K-M., Kallio T. and Grossi G. (2017), "Performance measurement in universities: ambiguities in the use of quality versus quantity in performance indicators", Public Money \& Management, Vol. 37 No. 4, pp. 293-300. 
Kastberg, G. and Lagström, C. (2019), "Processes of hybridization and de-hybridization: organizing and the task at hand", Accounting, Auditing \& Accountability Journal, Vol. 32 No. 3, pp. 710-726.

Knorr-Cetina, K. (1999), Epistemic Cultures. How the Sciences Make Knowledge, Harvard University Press, Cambridge.

Koppell, J. (2005), "Pathologies of accountability: ICANN and the challenge of "multiple accountabilities disorder", Public Administration Review, Vol 65 No. 1, pp. 94-108.

Kreps, T. and Monin B. (2011), ““'Doing well by doing good”? Ambivalent moral framing in organizations”, Research in Organizational Behavior Research in Organizational Behavior, Vol. 31 No. 2, pp. 99-123.

Lapsley, I. (1988), "Research in public sector accounting: an appraisal", Accounting, Auditing \& Accountability Journal, Vol. 1 No. 1, pp. 21-33.

Lepak, D.P., Smith, K.G. and Taylor, M. (2007), "Value creation and value capture: a multilevel perspective", Academy of Management Review, Vol. 32 No. 1, pp. 180-194.

Llewellyn, S. and Northcott D. (2005), "The average hospital”, Accounting, Organizations and Society, Vol. 30 No. 6, pp. 555-583.

Luke B., Barraket J. and Eversole R. (2013), "Measurement as legitimacy versus legitimacy of measures: performance evaluation of social enterprise", Qualitative Research in Accounting \& Management, Vol. 10 No. 3/4, pp. 234-258.

March, J. (1987), "Ambiguity and accounting: the elusive link between information and decision making", Accounting, Organizations and Society, Vol. 12 No. 2, pp. 153-168.

Marginson, S. (2007), "The public/private divide in higher education: a global revision", Higher Education Vol. 53, pp. 307-333.

Mayston, D. (1993), "Principals, agents and the economics of accountability in the new public sector", Accounting, Auditing \& Accountability Journal, Vol. 6 No. 3, pp. 68-96.

Merton, R. (1976), Sociological Ambivalence and Other Essays, Free Press, New York.

Meyer, M.W. (2002). Rethinking Performance Measurement. Beyond the Balanced Scorecard, Cambridge University Press, Cambridge.

Meyer, M. (2007), "Finding performance: the new discipline in management", in Neely A. (Ed.), Business Performance Measurement: Unifying Theory and Integrating Practice, Cambridge University Press, Cambridge, pp.113-124.

Miller P., Kurunmäki L. and O'Leary T. (2008), “Accounting, hybrids and the management of risk, Accounting, Organizations and Society”, Vol. 33 No. 7-8, pp. 942-967. 
Modell, S. (2003), "Goals versus institutions: the development of performance measurement in the Swedish university sector", Management Accounting Research, Vol. 14 No. 4, pp. 333-359.

Modell, S. (2005), "Students as consumers?: An institutional field-level analysis of the construction of performance measurement practices", Accounting, Auditing \& Accountability Journal, Vol. 18 No. 4, pp. 537-563.

Mouritsen J. and Kreiner K. (2016), “Accounting, decisions and promises”, Accounting, Organizations and Society, Vol. 49, pp. 21-31.

Mulgan, R. (2000), “Accountability: an ever-expanding concept? Public Administration, Vol. 78 No. 3, pp. $555-573$.

Nelson, R. (1993), National Innovation systems: A Comparative Analysis, Oxford University Press, New York. Nicholls, A. (2009), “'We do good things, don't we?': 'Blended Value Accounting' in social entrepreneurship", Accounting, Organizations and Society, Vol. 34, pp. 755-769.

Noordegraaf, M. (2007), "From "pure" to "hybrid" professionalism: present-day professionalism in ambiguous public domains”, Administration \& Society, Vol. 39 No. 6, pp. 761-785.

Noordegraaf, M. and Abma T. (2003), "Management by measurement? Public management practices amidst ambiguity, Public Administration, Vol. 81 No. 4, pp. 853-871.

Pache, A. and Santos F. (2013), "Inside the hybrid organization: selective coupling as a response to competing institutional logics”, Academy of Management Journal, Vol. 56 No. 4, pp. 972-1001.

Padgett, J. and Powell W. (2012), Emergence of Organizations and Markets, Princeton University Press, Princeton.

Parker, L. (2011), “University corporatisation: driving redefinition”, Critical Perspectives on Accounting, Vol. 22, pp. $434-450$.

Parker, L. and Guthrie, J. (2014), “Addressing directions in interdisciplinary accounting research”, Accounting, Auditing \& Accountability Journal, Vol. 27, No. 8, pp. 1218-1225.

Porter, T. (1995), Trust in Numbers: The Pursuit of Objectivity in Science and Public Life, Princeton University Press, Princeton.

Porter, T. (2008), "Locating the domain of calculation”, Journal of Cultural Economy, Vol 1 No. 1, pp. 39-50. Powell, W. (1990), "Neither market nor hierarchy", in Staw B. and Cummings L. (Eds.) Research in organizational behavior 12, JAI Press, Greenwich, pp. 295-336. 
Powell, W. and Owen-Smith, J. (1998), "Universities and the market for intellectual property in the life sciences", Journal of Policy Analysis and Management, Vol, 17, pp. 253-277.

Power, M. (2000), “The audit society - second thoughts", International Journal of Auditing, Vol. 4 No. 1, pp. 111-119.

Power M. (2015), "How accounting begins: object formation and the accretion of infrastructure, Accounting, Organizations and Society, Vol. 47, pp. 43-55.

Ranga, M. and Etzkowitz H. (2013), "Triple helix systems: an analytical framework for innovation policy and practice in the knowledge society", Industry and Higher Education, Vol. 27 No. 4, pp. 237-262.

Reay, T. and Hinings C. (2009), "Managing the rivalry of competing institutional logics", Organization Studies, Vol. 30 No. 6, pp. 629-652.

Roberts, R.W. (2004), "Managerialism in US universities: implications for the academic accounting profession", Critical Perspectives on Accounting, Vol. 15 Issues 4-5, pp. 461-467.

Schillemans, T. (2011), "Does horizontal accountability work? Evaluating potential remedies for the accountability deficit of agencies", Administration \& Society, Vol. 43 No. 4, pp. 387-416.

Shore, C. \& Taitz, M. (2012), "Who 'owns' the university? Institutional autonomy and academic freedom in an age of knowledge capitalism", Globalisation, Societies and Education, Vol. 10 No. 2, pp. 201-219

Skelcher, C. and S. Smith (2015), "Theorizing hybridity: institutional logics, complex organizations, and actor identities: the case of nonprofits", Public Administration, Vol. 93 No. 2, pp. 433-448.

Smith, P. (1995), "On the unintended consequences of publishing performance data in the public sector", International Journal of Public Administration, Vol. 18 No. 2-3, pp. 277-310.

Smith, W. K., and Lewis, M. W. (2011), "Toward a theory of paradox: a dynamic equilibrium model of organizing", Academy of Management Review, Vol. 36 No. 2, pp. 381-403.

Speklé R.F., and Verbeeten F.H.M. (2014), "The use of performance measurement systems in the public sector: effects on performance", Management Accounting Research, Vol. 25 No. 2, pp. 131-146.

Stark, D. (2009), The Sense of Dissonance: Accounts of Worth in Economic Life, Princeton University Press, Princeton.

ter Bogt H.J. (2003), "Performance evaluation styles in governmental organizations: how do professional managers facilitate politicians' work?”, Management Accounting Research, Vol. 14 No. 4, pp. 311-332.

Thynne, I. (2011), "Ownership as an instrument of policy and understanding in the public sphere: trends and research agenda", Policy Studies, Vol. 32 No. 3, pp. 183-197. 
Vakkuri, J. and Meklin, P. (2006), “Ambiguity in performance measurement - a theoretical approach to organisational uses of performance measurement", Financial Accountability and Management, Vol. 22 No. 3, pp. 235-250.

van Helden, J., Johnsen Å. and Vakkuri J. (2008), "Distinctive research patterns on public sector performance measurement of public administration and accounting disciplines", Public Management Review, Vol. 10 No. 5, pp. 641-651.

van Helden, J. and Reichard, C. (2019), "Making sense of the users of public sector accounting information and their needs", Journal of Public Budgeting, Accounting \& Financial Management, Vol. 31 No. 4, pp. $478-495$.

Verbeeten, F.H.M. (2008), "Performance management practices in public sector organizations: impact on performance”, Accounting, Auditing \& Accountability Journal, Vol. 21 No. 3, pp. 427-454.

Vries, P. and Yehoue, E. (2013), The Routledge Companion to Public-Private Partnerships, Routledge, New York.

Weick, K. E. (1976), "Educational organizations as loosely coupled systems”, Administrative Science Quarterly, Vol. 21, pp. 1-19.

Whitley, R. (2000), The Intellectual and Social Organization of the Sciences, Oxford University Press, New York.

Williamson, O.E. (1999), The Mechanisms of Governance, Oxford University Press, New York. 
Table 1. Performance measurement ambiguities in hybrid universities

\begin{tabular}{|c|c|c|c|c|}
\hline $\begin{array}{l}\text { Characteristics } \\
\text { of hybridity/ } \\
\text { measurement } \\
\text { principles }\end{array}$ & $\begin{array}{l}\text { Market } \\
\text { approach }\end{array}$ & State approach & $\begin{array}{l}\text { Academic } \\
\text { oligarchy } \\
\text { approach }\end{array}$ & $\begin{array}{l}\text { Approaches combined: } \\
\text { ambiguity of performance } \\
\text { measurement in hybrid } \\
\text { universities }\end{array}$ \\
\hline $\begin{array}{l}\text { Measuree: How } \\
\text { is the object of } \\
\text { measurement } \\
\text { understood? }\end{array}$ & $\begin{array}{l}\text { Universities as } \\
\text { service } \\
\text { providers }\end{array}$ & $\begin{array}{l}\text { Universities as } \\
\text { institutions } \\
\text { contributing to the } \\
\text { policy goals and } \\
\text { intellectual capital } \\
\text { of society }\end{array}$ & $\begin{array}{l}\text { Universities as a } \\
\text { scientific } \\
\text { community: a } \\
\text { collection of } \\
\text { academic tribes }\end{array}$ & $\begin{array}{l}\text { Organizational lock-in } \\
\text { problem } \\
\text { What is a university? } \\
\text { What kind of performance } \\
\text { can we expect from } \\
\text { universities? }\end{array}$ \\
\hline $\begin{array}{l}\text { Measurer: Who } \\
\text { measures? }\end{array}$ & $\begin{array}{l}\text { Students, } \\
\text { partners and } \\
\text { constituencies }\end{array}$ & $\begin{array}{l}\text { Science and } \\
\text { higher education } \\
\text { policy actors }\end{array}$ & $\begin{array}{l}\text { Peers, colleagues, } \\
\text { other universities } \\
\text { and academic } \\
\text { institutions }\end{array}$ & $\begin{array}{l}\text { Problem of multiple } \\
\text { accountabilities } \\
\text { Whose value should be } \\
\text { increased? } \\
\text { Impacts on whom? }\end{array}$ \\
\hline $\begin{array}{l}\text { Measurement } \\
\text { system: How are } \\
\text { the rules of } \\
\text { performance } \\
\text { measurement } \\
\text { defined? }\end{array}$ & $\begin{array}{l}\text { Performance } \\
\text { as meeting the } \\
\text { needs and } \\
\text { expectations of } \\
\text { constituencies }\end{array}$ & $\begin{array}{l}\text { Performance as } \\
\text { the attainment of } \\
\text { policy goals }\end{array}$ & $\begin{array}{l}\text { Performance as } \\
\text { novel research and } \\
\text { high-quality } \\
\text { teaching }\end{array}$ & $\begin{array}{l}\begin{array}{l}\text { Ambiguity of } \\
\text { simplification }\end{array} \\
\text { How is the rule system } \\
\text { defined? How is the } \\
\text { performativity of } \\
\text { universities produced? }\end{array}$ \\
\hline $\begin{array}{l}\text { Measurement } \\
\text { results: How are } \\
\text { performance } \\
\text { measurements } \\
\text { legitimized? }\end{array}$ & $\begin{array}{l}\text { Legitimization } \\
\text { through } \\
\text { satisfaction } \\
\text { and choice }\end{array}$ & $\begin{array}{l}\text { Legitimization } \\
\text { through the } \\
\text { attainment of } \\
\text { policy goals }\end{array}$ & $\begin{array}{l}\text { Legitimization } \\
\text { through the } \\
\text { reproduction and } \\
\text { accumulation of } \\
\text { scientific } \\
\text { knowledge }\end{array}$ & $\begin{array}{l}\text { Legitimacy bifurcation } \\
\text { Who should be convinced } \\
\text { of university performance? }\end{array}$ \\
\hline
\end{tabular}

